\title{
The Efficient Role of Dermestes in Damage of Fish in Bangui (Central African Republic)
}

\author{
Bolevane-Ouantinam Serge Florent ${ }^{1}$, Aba-Toumnou Lucie ${ }^{2 *}$, Gondi Armelle Judith ${ }^{3}$, \\ Wango Solange Patricia ${ }^{1}$, Zinga Innocent ${ }^{2}$, Namkosséréna Salomon ${ }^{3}$, \\ Lakouèténé Didier Ponel-Béranger ${ }^{2}$, Kongueret Ernest ${ }^{4}$, Semballa Silla ${ }^{2}$ \\ ${ }^{1}$ Laboratory of Applied Animal Biology and Biodiversity, University of Bangui, Bangui, Central African Republic \\ ${ }^{2}$ Laboratory of Biological and Agronomical Sciences for Development, Bangui, Central African Republic \\ ${ }^{3}$ Regional Pole of Applied Research to Development, Farming Systems in Central Africa (PRASAC), Djamena, \\ Chad \\ ${ }^{4}$ Central African Republic Institute of Agronomical researches (ICRA), Bangui, Central African Republic \\ Email: ${ }^{*}$ toumnou@yahoo.fr
}

Received 24 April 2015; accepted 29 June 2015; published 2 July 2015

Copyright (C) 2015 by authors and Scientific Research Publishing Inc.

This work is licensed under the Creative Commons Attribution International License (CC BY). http://creativecommons.org/licenses/by/4.0/

(c) (i) Open Access

\begin{abstract}
A bad conservation of food is recognized as being one of the critical constraints upon food security among resource poor population across Africa. We have evaluated the traditional management of pests in fish in Central African Republic. The data were analyzed by a factor analysis of correspondence. The Group I contained sensitive species of fish to the attacks of Dermetes frishii, Dermetes lardarius and Dermestes carnivorus. There were: Labeocoubie, Mormyrus deliciosus, Polydactylus quadrifilis, Auchenoglanis occidentalis, Synodontis nigrita, Hydrocynus forskalli, Districhodus rostratus, Hydrocynus goliath and Mormyrusrume. The group II contained sensitive species of fishes to the attacks of $D$. maculatus. There were: Cyprinus carpio, Malapterurus electricus, Oreochromis mossambicus, Barbus occidentalis and Oreochromis mossambicus. Clariasgariecilus is the mostsensitive of dried fish to the attacks of Dermestes. Oreochromis mossambicus, Mormyrusrume and Synodontis nigrita are the last sensitive of dried fish to the attacks of Dermestes. The results showed that the tradictional management of dried fish in Central African Republic couldn't be efficient for reducing the development of Dermestes.
\end{abstract}

\section{Keywords}

Traditonal Management, Pests, Dried Fish

"Corresponding author.

How to cite this paper: Florent, B.-O.S., Lucie, A.-T., Judith, G.A., Patricia, W.S., Innocent, Z., Salomon, N., Ponel-Béranger, L.D., Ernest, K. and Silla, S. (2015) The Efficient Role of Dermestes in Damage of Fish in Bangui (Central African Republic). Advances in Entomology, 3, 111-117. http://dx.doi.org/10.4236/ae.2015.33013 


\section{Introduction}

Fish are one of the major sources of protein that can significantly improve the livelihood of the rural poor and increase foreign exchange earnings for many African countries [1] [2]. In CAR, fish are marketed and play an important economic role among the small fishermen. However, insects are key constraints to fish production in CAR. One of the insects causing damage in fish is the larder beetle (Dermestes lardarius L.).

The genus of Dermetes is a commercial pest as well as a household pest. The use of refrigeration, the purchase of meats in small quantities, and the lack of home curing of meats, have decreased the economic importance of this insect [3]. However, these beetles are still common in homes, museums, mills, livestock facilities, and any place that contains a suitable food source. Typically, these would include any animal by-product such as dried dog food, furs, hides, and feathers [4]. Also, many pantry items can become infested. Another potential food source is dead insects in attic and wall voids that become trapped when they seek an overwintering site. In the fall insects such as flies, bugs, beetles and wasps, accumulate in attics and similar spaces in the home [5]. The hypothesis of this work was that traditional management of pests in dried fish could be or not the efficient technique for reducing the population of Dermestes causing damages in dried fish in CAR.

\section{Material and Methods}

\subsection{Choice of Surveyed Sites and Data Collection}

The Central African Republic is situated just north of the Equator with daily temperatures normally reaching at least 30 degrees Celsius. Bangui (Figure 1) is the Capital of Central African Republic and close to the Equator in the south of the country is slightly hotter and wetter than the northern regions [6]. The latitude and longitude of Bangui are respectively N: $4^{\circ} 21.6732^{\prime}$ and E: $18^{\circ} 33.2976^{\prime}$. Bangui, close to the Equator in the south of the country is slightly hotter and wetter than the northern regions. The city is bordered by thick tropical rainforests along the river banks. Several of its neighbourhoods are in low-lying areas prone to recurrent flooding. Severe rains in June and July 2009 left 11,000 people homeless. Bangui serves as an administrative, trade, and commercial center [7]. These sites have been considered for this study because of their high commercial of dried fish.

A questionnaire validated by Teachers-Researchers of the University of Bangui was focused on the traditional technique for conserving of fish. The questionnaire had two parts: the description of fishes and pests management. On the basis of local names; the fish are fitted, photographed fish and samples collected and authenticated by the researchers of the Forestry and Water Ministry of CAR.

In each Administration area, 20 to 30 infected dried fish were collected in different markets since August to October 2014. In the traditional method, the wood heater produces the energy for drying fish.

\subsection{Data Collection, Identification of Insects and Data Analysis}

A questionnaire was prepared and used as a tool for the collection of information with 224 sellers in the different markets of Bangui. The questionnaire focused on the traditional practices for dried fish against pests. On the basis of local names of fish and insects, the samples were collected for the identification of species names by the

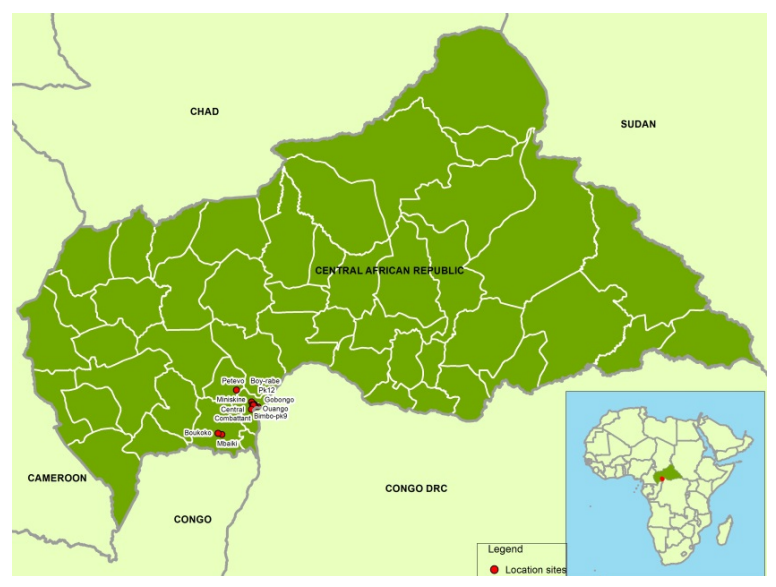

Figure 1. Location of surveyed markets in Bangui. 
Teacher-Researchers of University of Bangui. D. maculatus, D. frishii, D. lardarius and D. carnivorus were collected on 20 species of fish (Table 1) selling in the different markets of Bangui. The insects were reared respectively on $30 \mathrm{~g}$ of dried fish in laboratory at $27^{\circ} \mathrm{C} \pm 2^{\circ} \mathrm{C}$ and $10 \pm 70 \mathrm{r}$. h. After 7 days of the spawning, adults are eliminated and eggs have evolved to give the first generation of adults from 50 to 60 days after infestation. Insects were characterized by microscopie and identified by using the key of identification [8].

A factorial analysis of correspondence with the software $R$ ( $R$ version 2.15.1) was used to identify the relation between species of dried fish and species of insects. Diagrams were also constructed to evaluate the specific abundance per insects and the dried fish used.

\section{Results}

\subsection{Insects Damage on Dried Fish}

Figure 2 shows some insect damage on dried fish in CAR. In general in this case of insects damage, the fish lose sits market value.

\begin{tabular}{lc} 
Table 1. Fish codification. & \\
\hline Fish' species & Codification \\
\hline Protopterus annectens & $\mathrm{Pa}$ \\
Auchenoglanis occidentalis & $\mathrm{Ao}$ \\
Mormyrus rume & $\mathrm{Mr}$ \\
Distichodus mossambicus & $\mathrm{Dm}$ \\
Mormyrus deliciosus & $\mathrm{Md}$ \\
Labeo coubie & $\mathrm{Lc}$ \\
Oreochromis mossambicus & $\mathrm{Om}$ \\
Barbus occidentalis & $\mathrm{Bo}$ \\
Hydrocynus forskalli & $\mathrm{Hf}$ \\
Malapterurus electricus & $\mathrm{Me}$ \\
Clarotes laticeps & $\mathrm{Cl}$ \\
Districhodus rostratus & $\mathrm{Dr}$ \\
Clarias gariecilus & $\mathrm{Cg}$ \\
Lutjanu ssp & $\mathrm{Ls}$ \\
Synodontis nigrita & $\mathrm{Sn}$ \\
Gnatonemus tamandua & $\mathrm{Gt}$ \\
Polydactylus quadrifilis & $\mathrm{Pq}$ \\
Channa obscuris & $\mathrm{Co}$ \\
Cyprinus carpio & $\mathrm{Cc}$ \\
Hydrocynus goliath & $\mathrm{Hg}$ \\
\hline
\end{tabular}

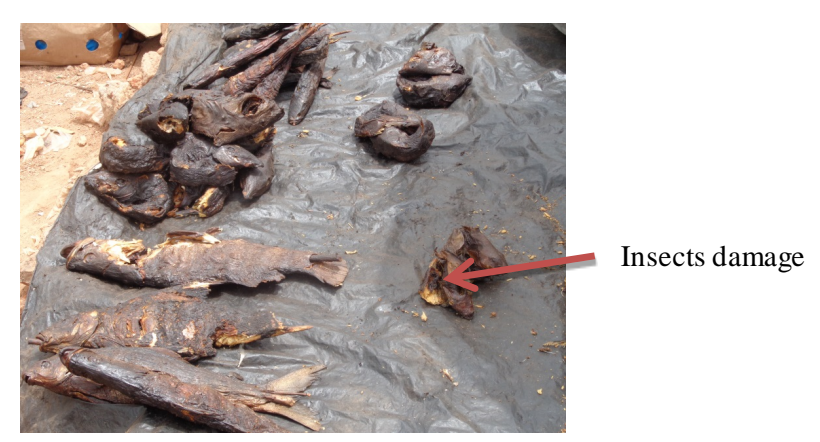

Figure 2. Insects damage on dried fish (Aba Toumnou, 2014). Clariasgariecilus is the most sensitive of dried fish to the attacks of Dermestes (Figure 3). Oreochromismossambicus, Mormyrusrume and Synodontisnigrita are the most sensitive of dried fish to the attacks of Dermestes. 


\subsection{Fish Species and Insects Species Relation}

The eigen values of the principal axes extracted from the factor analysis of correspondence indicated that the first two factors explained $80 \%$ of the matrix dried fish/Insects species information (Figure 4). The factorial plane formed by these two axes (Dim 1 and Dim 2) defined two groups of dried fish/Insects species (Figure 4). The Group I contained sensitive species of dried fish to the attacks of $D$. frishii, $D$. lardarius and $D$. carnivorus. There were: Labeocoubie, Mormyrus deliciosus, Polydactylus quadrifilis, Auchenoglanis occidentalis, Synodontis nigrita, Hydrocynus forskalli, Districhodus rostratus, Hydrocynus goliath and Mormyrusrume.

The group II contained sensitive species of fish to the attacks of D. maculatus. There were: Cyprinuscarpio, Malapterurus electricus, Oreochromis mossambicus, Barbus occidentalis and Oreochromis mossambicus.

\section{Discussion}

The worked hypothesis was that the traditional management of dried fish in CAR could or not promote the

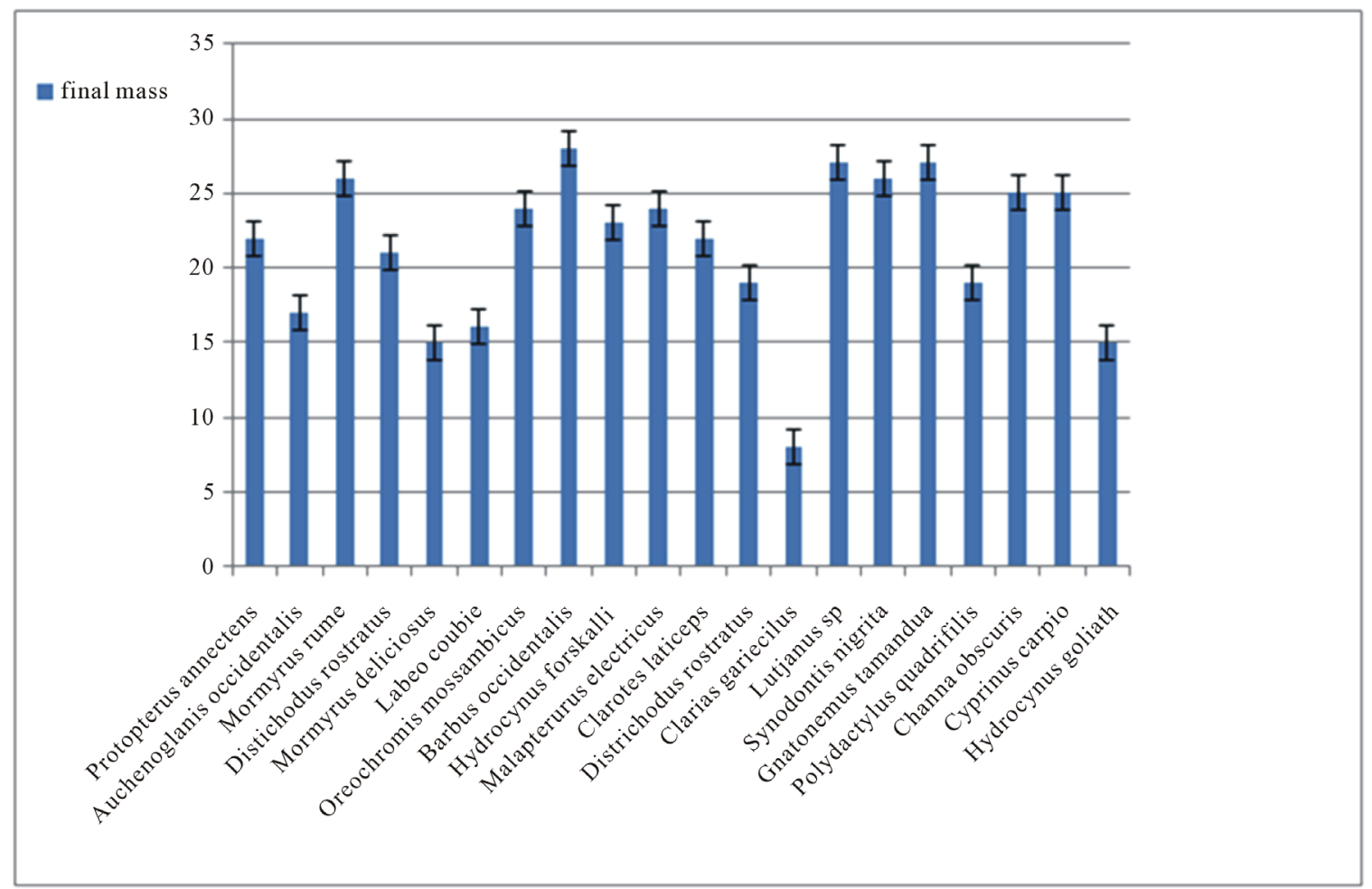

Figure 3. Final mass of fish’ species after rearing according to Excel version 2003.



Figure 4. Fish species/insects by a factorial analysis of correspondence (FAC). 
development of the insects of the genus Dermestes. The study was performed on 20 dried fish species. Ten days after the livestock development, insect larvae have emerged in the various jars and two types of morphologically different larvae were identified. Some larvae are brown and have hair less developed unlike others that are black and carry a lot of well-developed hairs and showed that the larvae of insects Dermestes kind are hairy [3]. The observation by the microscope of the first larval form highlights the presence of a head with an elongated body left in several segments. We also note the presence of three pairs of thoracic legs and appendages. Abdominal pseudopods are absent; this is an elateriform type of larva. The larvae belong to the family of Dermestes. Some adult of insects are oval, slightly flattened and approximately 5/16- to 7/16-inch long. It is unmistakable because of its brilliantly colored, metallic green body and wing covers (elytra), which vary from copper (red-pink) to bronze (yellow-brown). Elytra do not cover the entire abdomen, leaving five distinct tufts of white hair visible along each side. Another pair of tufts adorn the back of the last abdominal segment. Fine grey hairs appear on the underside of the body [9]. Some authors [10] [11] reported that it's possible emerging of Dermestes ladarmius adults to pair and kept under the same conditions when their fecundity and longevity were recorded. Complete development of some larvae occurred under all conditions except $12.5^{\circ} \mathrm{C}$ but I2 of the 13 adults produced at $15^{\circ} \mathrm{C}$ were deformed and mortality at $32.5 \mathrm{C}$ was very high. The period from egg hatch to emerge adult ranged from about 145 days at $15^{\circ} \mathrm{C}$ to about 48 days at $25^{\circ} \mathrm{C}$ and above [12]. At $25^{\circ} \mathrm{C}$ most rapid development was found at the highest humidity used. Adults lived from up to 61 days at $15^{\circ} \mathrm{C}$ to over 300 days at the higher humidities at $25^{\circ} \mathrm{C}$. Above this temperature life was shorter, up to 169 days at $3^{\circ} \mathrm{C}$ and up to only 23 days at $32.5^{\circ} \mathrm{C}$.

On the $30 \mathrm{~g}$ of each species of dried fish weighed for some species almost half was consumed by Dermestes, for others more than half. Nutrition of larvae and adults of Dermestes spp. causes considerable quantitative loss of dried fish and fragmentation [8] [2] [13] [14]. The importance and value of quantitative losses caused to dried fish by Dermestesspp were evaluated by different researchers and estimates range from insignificant (20\% to $50 \%$ weight loss) depending on the duration of storage, the salt content, humidity, weather conditions and general conditions of hygiene during treatment storage [15] [16]. Our results showed that some of these dried fish species (Districhodus mossambicus, Clarias garieculis, Polydactylus quadrifilis, Cyprinus carpio and Hydrocynus goliath) are favor to the development of Dermestes.

Beetles of the genus Dermestes L. have long been recognized as pests of animal products, particularly hides and skins. The annual loss caused by Dermestes attack on hides and skins in South Africa amounted was estimated to $£ 750,000$ [17]. The worth of damage per year to hides and skins in the U.S.A. is estimated in $\$ 1,000,000$ [18]. The problem is, therefore, both serious and widespread. In each of these countries the main pest was Dermestes maculatus. Larvae of Dermestes also infest dried fish [19]. There appear to be few published evaluations of the resultant losses, but another work [16] estimated that the financial loss from insect damage to dried fish produced on the Nigerian shores of Lake Chad may amount to $£ 500,000$ annually. Other commodities that hide beetles can damage include stored animal products such as dried fish, cheese, hide, fur, bacon, and dog treats. The larvae can cause considerable damage to timber, cork, plaster, linen, and cotton when they bore into these materials to pupate [20].

Oreochromis mossambicus, Mormyrus rume and Synodontis nigrita are the most sensitive of dried fish to the attacks of Dermestes in our work.

After twenty-one (21) days, observing the microscope reveals the presence of nymphs. This would be a chrysalis or pupa mummy. The appendices are glued to the body. They appear whitish, motionless, locked in a cocoon with appendices glued to the body.

Some works [10] [21] [22] showed that the nymphs or pupae are Dermestes mummy, whitish and enclosed in a cocoon with appendages stuck to the body.

From 31 days after the livestock development, adult insects begin to emerge. Adults who have emerged are of two types. There are differences in their color, shape and mobility, but all have a pair of antenna, three pairs of legs, two pairs of wings according the key of identification [8]. D. carnivorus, D. frischii, D. maculatus, are characterized by dense hair (chalky, whitish, yellowish orange or brown) on the ventral side of the abdomen, which mask the chitine. The pronotum is massive and is $1 / 3$ the length of the elytra. Pronotum almost completely covered in brown silk and red, or long, very characteristic. Elytra black, speckled with fine short whitish hairs gray-blue, lying and more or less forming waves or zigzag. The ventral surface of the abdomen covered with hairs with white bristles, each sternum, two lateral black spots. The last sternum is almost entirely black, but there are 2 isolated white spots adjacent to the front edge of the segment. 


\section{Conclusion}

The results showed that the traditional management of dried fish in Central African Republic could be efficient for some dried fish as Oreochromis mossambicus, Mormyrus rume and Synodontis nigrita but not for another species as Clariasgariecilus. The traditional management of dried fish in Central African Republic couldn't reduce the development of some species of Dermestes (D. carnivorus, D. frischii, D. maculatus).

\section{Acknowledgements}

The authors are grateful to Dr. Serge-FlorentBolevane, Head of the division of Life Sciences in Faculty of Sciences of University of Bangui and Dr. SillaSemballa, Director of the Laboratory of Biological and Agronomical Sciences for Development for providing facilities and materials to conduct this study. Our sincere thank also to Dr. Namkosséréna Salomon, Executive Thief of Regional Pole of Applied Research to Development Farming Systems in Central Africa for its contribution.

\section{References}

[1] Aref, M., Timbley, A. and Daget, J. (1964) Fish and Fist Processing in Republic of Mali. 3. On the Destruction of Fish by Dermestes Insects. AlexandriaJournal of Research, 12, 95-98.

[2] Dransfield, E. (2006) Facteurs influençant les qualités physiques, chimiques et organoleptiques des poissons d'eau douce. Pays-Bas, 14 p.

[3] Haines, C.P. and Rees, D.P. (1989) Dermestes spp. A Field Guide to the Types of Insects and Mites Infesting Cured Fish. http://www.fao.org/docrep/003/t0146e/T0146E04.htm.

[4] Cloud, J.A. and Collison, C.H. (1986) Comparison of Various Poultry House Litter Components for Hide Beetle (Dermestes maculatus DeGeer) Larval Development in the Laboratory. Poultry Science, 65, 1911-1914. http://dx.doi.org/10.3382/ps.0651911

[5] Kumar, P., Jayaprakas, C.A., Singh, B.D. and Sen-Gupta, K. (1988) Studies on the Biology of Dermestesater (Coleoptera: Dermestidae)—A Pest of Silkworm Pupae and Adults. Current Science, 57, 1253-1259.

[6] Boulvert, Y. (1986) Carte phytogéographique de la République centrafricaine à 1:1000000e. ORSTOM éd., Coll. Notice Explicative, Paris, 131 p.

[7] Conaway, J.L., Ouedraogo, A.K. and Coneff, J. (2012) Activité de zonage plus de moyens d'existence de la République centrafricaine. USAID (United States Agency International Development), Bangui, Centrafrique, 41p.

[8] Delobel, A. and Tran, M. (1993) Les Coléoptères des denrées alimentaires entreposées dans les régions chaudes. ORSTOM, Paris, $424 \mathrm{p}$.

[9] Wang, J., Li, Z., Chen, Y., Chen, Q. and Yin, X. (2008) The Succession and Development of Insects on Pig Carcasses and Their Significances in Estimating PMI in South China. Forensic Science International, 179, 11-18. http://dx.doi.org/10.1016/j.forsciint.2008.04.014

[10] Adams, R.G. (1980) Dermestes leechi Kalik in Stored Products and New Diagnostic Characters for Dermestes spp (Coleoptera: Dermestidae). Journal of Stored Products Research, 16, 119-122. http://dx.doi.org/10.1016/0022-474X(80)90008-9

[11] Richardson, M.S. and Goff, M.L. (2001) Effects of Temperature and Intraspecific Interaction on the Development of Dermestes maculatus (Coleoptera: Dermestidae). Journal of Medical Entomology, 38, 347-351. http://dx.doi.org/10.1603/0022-2585-38.3.347

[12] Rajashekhargouda, R. and Devaiah, M.C. (1986) Biology of the Carpet Beetle, Attagenusfisciutus (Thunberg) (Col. Dermestidae) and Loss Estimation. Mysore Journal of Agricultural Sciences, 20, 43-51.

[13] McNamara, K.B., Brown, R.L., Elgar, M.A. and Jones, T.M. (2008) Paternity Costs from Polyandry Compensated by Increased Fecundity in the Hide Beetle. Behavioral Ecology, 19, 433-440. http://dx.doi.org/10.1093/beheco/arm153

[14] Nijhout, H.F., Riddiford, L.M., Mirth, C., Shingleton, A.W., Suzuki, Y. and Callier, V. (2014) The Developmental Control of Size in Insects. WIREsDev.Biol., 3, 113-134.

[15] Howe, R.W. (1953) The Effects of Temperature and Humidity on the Length of the Life Cycle of Dermestes frischii (Kug.) (Col., Dermestidae). Entomologist, 86, 109-113.

[16] Owoade, R.A. (2008) Mortality, Growth and Development of Dermestes maculatus Larvae Exposed to Dry Clarias sp. Treated with Four Local Spices. African Scientist, 9, 30-34.

[17] Kritzinger, C.C. (1955) The Control of Insect Damage to Hides and Skins. Science Direct, 156, 159-167. 
[18] Howard, G.T. (1952) The Destructive Hide Beetle; Its Hide and Skin Damage Costs Amount to \$1,000,000 a Year. Science Direct, 123, 16, 42-44.

[19] Kalshoven, L.G.E. (1954) Dermestids in Indonesia-4: On the Development of Dermestes Species on Dried Fish and Meat in Java. Science Direct, 15, 112-116.

[20] Veer, V., Negi, B.K. and Rao, K.M. (1996) Dermestid Beetles and Some Other Insect Pests Associated with Stored Silkworm Cocoons in India, Including a World List of Dermestid Species Found Attacking This Commodity. Journal of Stored Products Research, 32, 69-89. http://dx.doi.org/10.1016/0022-474X(95)00032-3

[21] Jones, T.M., McNamara, K.B., Colvin, P.G.R., Featherston, R. and Elgar, M.A. (2006) Mating Frequency, Fecundity and Fertilization Success in the Hide Beetle, Dermestes maculatus. Journal of Insect Behavior, 19, 357-371. http://dx.doi.org/10.1007/s10905-006-9032-5

[22] Smykal, V., Daimon, T., Kayukawa, T., Takaki, K., Shinoda, T. and Jindra, M. (2014) Importance of Juvenile Hormone Signaling Arises with Competence of Insect Larvae to Metamorphose. Developmental Biology, 390, 221-230. http://dx.doi.org/10.1016/j.ydbio.2014.03.006 